\title{
Foundational Memes for a New Narrative About the Role of Business in Society
}

\author{
Sandra Waddock ${ }^{1}$
}

Received: 10 November 2015 / Accepted: 17 January 2016/Published online: 29 July 2016

(C) Springer International Publishing 2016

\begin{abstract}
This paper argues that memes form the basis of our cultural narratives, and that today's dominant memes need to dramatically shift to contend with the realities of growing inequality and climate change, which could pose existential threats to humanity. The paper offers a potential set of memes that could be used to develop a business and economic narrative that allows for inclusiveness, wellbeing and dignity for all, while still emphasizing a prosperous business community but not allowing it to dominant societal thinking. New memes proposed focus at the societal level arguing that societies (and businesses) are deeply intertwined with nature, that goals should emphasize wellbeing and dignity for all, defining 'wealth' as collective value and dignity as reverence for humans, living beings, and Nature itself. Relevant capitals are multiple, including economic/financial, human/intellectual, social/ relational, natural/ecological, and spiritual/reverence. Core values include freedom and democracy within constraints of dignity and an ecologically sustainability social contract, creating 'fair' markets, 'glocal-ism,' both private and public goods, and collaboration combined with competition. Governments play important roles in setting fair laws and regulations and business' purpose becomes maximizing aggregate wellbeing within ecological constraints without dignity violations.
\end{abstract}

Keywords Memes $\cdot$ Wellbeing $\cdot$ Foundational economic narrative $\cdot$ Economic values Sustainabilty $\cdot$ Dignity $\cdot$ Narrative

The world is different from what it has ever been before. Some of the differences reflect a new reality that can be hard to acknowledge: human civilization cannot prosper tomorrow without significant system change today (c.f., Hawken et al. 2013; Ehrenfeld and Hoffman 2013; Fullerton 2015). Scientists studying planetary boundaries argue that human population growth with its manifold impacts, i.e., what they term the human enterprise, is now destabilizing the

Sandra Waddock

waddock@bc.edu

1 Boston College, Carroll School of Management, Chestnut Hill, MA 02467, USA 
geologic era known as the Holocene. What is substituted is a new geological era called the Anthropocene that reflects human intervention in global ecosystems (Steffen et al. 2015).

Never before has humanity had the power to change climate in ways that pose the threat of a great disruption (Gilding 2011), and possibly a much worse, even existential, catastrophe (Lovelock 2010; Ehrenfeld and Hoffman 2013; IPCC 2014). Never before has human influence created a mass extinction threatening as much as three quarters of animal life (Larsen 2004; Leakey and Lewin 1996; Barnosky et al. 2011), or pushed so many ecosystems and planetary boundaries beyond sustainable limits (Speth 2008; Ehrenfeld and Hoffman 2013; Rockström et al., 2009; Steffen et al. 2015). Yet all of these human-induced problems now exist.

But wait, there's more, as many advertisements say. Today's rampant inequality could possibly reprise past civilizations in which the very rich controlled much of the wealth. But the fact that 62 individuals - individuals! - in 2016 controlled as much wealth as the poorest half of the world's population, or more than 3.5 billion people (Oxfam 2016), suggests the extreme to which today's wealth gap has now gone. This inequality gap, which is still growing, suggests that the potential for problems brewing around inequality is very real. This stark reality has already been made manifest by uprisings and protests in numerous countries, particularly around lack of economic opportunities and jobs.

In contrast to the current global situation, Raworth (2012) argued in her 'doughnut' that a flourishing future for humankind needs to go beyond ensuring that the nine ecological planetary boundaries identified are not breached (beyond what has already happened, to be sure) (Rockström et al., 2009; Steffen et al. 2015). Raworth argues that there are eleven core social foundations for healthy, prospering societies, including sufficient water, food, income, health, gender equity, social equity, energy, jobs, voice, and resilience. These social elements, she argues, create a set of social boundary conditions for a 'safe and just space for humanity to thrive in' (Raworth 2012, p. 4). Notably, most of these social foundations and others are also included in the United Nations' Sustainable Development Goals for 2015-2030. ${ }^{2}$

In what follows, I will argue that memes form the basis of our cultural narratives, and that today's dominant memes need to dramatically shift to contend with the types of realities highlighted above (see Waddock 2015b). The paper offers a potential set of core memes that could be used to develop a business and economic narrative that allows for inclusiveness, wellbeing and dignity for all, while still emphasizing a prosperous business community but not allowing it to dominant societal thinking.

\section{Memes, Narrative, and Cultural Mythologies}

In the context of these ecological and inequality challenges, both of which can be causes of civilizational collapse (Diamond 2005), it is increasingly clear that we - globally - need to develop a new mindset of planetary stewardship that pervades all of the world's large systems including, importantly, businesses and the economic system. The challenges to better planetary stewardship are immense, in part because many of the powerful memes that shape our current civilizations, understandings, and belief systems about our relationship to the world around us

\footnotetext{
${ }^{1}$ See the Humanistic Management Network: http:/humanetwork.org/. This paper elaborates the Humanistic Management Network's core constructs of wellbeing and dignity.

${ }^{2}$ United Nations Sustainable Development Goals, (http://www.un.org/sustainabledevelopment/sustainabledevelopment-goals/:
} 
are deeply problematic and largely emphasize economic rather than a broader societal set of values (Waddock 2015b).

Memes are foundational cultural artifacts that shape belief systems, attitudes, ideologies, and the like (Blackmore 2000). They can be phrases, words, images, or other types of artifacts that resonate with people and, essentially, form the foundations of attitudes, beliefs, and understandings (Blackmore 2000). Such memes are collected into in the narratives that represent our cultural mythologies and define how we view the others and the world around us. Resonant memes 'replicate' by being used by many people, either because they are instantly recognizable or because they are values-based in ways that attract people. Memes are central and often unrecognized elements in creating the type of societal narratives that help us as humans relate to the world around us. Arguably, understanding how to use memes effectively is a central and often overlooked aspect of system change (Waddock 2015b). Shifting core memes, related mindsets, and the consequent narrative that tells us how things 'are' is a crucial first step in major systemic change.

I want to argue that it is the shamans among us, particularly in their role as sensemakers, who can articulate and help people understand new and resonant memes and their associated narrative. The shaman is the healer, connector, and sensemaker, the medicine person, in traditional communities, often a centrally important figure (Waddock 2015a; Frost and Egri 1994; Egri and Frost 1991). Shamans are deeply connected to the world around them. In traditional cultures, shamans believe that everything is endowed with spirit - including not just other living beings, but also earthly manifestations like lakes, rivers, rocks, trees, and mountains and, indeed, the Earth itself. Like modern physicists, who note that everything is connected (e.g., Capra and Luisi 2014.), the shaman recognizes interconnection among people, other living beings, and the rest of the earth in ways that much of Western culture and particularly the dominant economic narrative do not.

The shaman understands that healing one part of the world can result in changes, hopefully positive, in other parts of the world because everything is connected, interactive, and interdependent. An important function of the shaman as sensemaker is in shaping and articulating memes relevant to healing the relevant cultural mythologies that have gotten the patient - in this case humankind and our relationship to Earth, the relative roles of economy and society, the purposes of business, for example — sick in the first place (Dow 1986). Modern shamans in all walks of life can arguably still function as healers, connectors, and sensemakers by creating new memes and ultimately new cultural mythologies that work for today's world better than today's dominant cultural myths.

In a sense, memes create the foundation of our 'origin narratives,' the cultural stories that shape our relationship to the world around us. In traditional cultures, shamans who are fundamentally healers, connectors, and sensemakers (Waddock 2015a) believe that when patients get sick, it is because the cultural mythologies surrounding them need healing (Dow 1986). As noted above, the patient - in this case human civilization in its relationship to the planet rather than an individual relating to a local mythology — is sick. Beginning the healing process involves reframing the problematic narrative and, if necessary, changing its underlying memes so that the patient(s) can heal (Dow 1986). Among other activities associated with healing, traditional shamans 'journey' to different (often spiritual) realms to gather information that can help them reconstruct the mythology in healing ways. Today, it is the neoclassical economics or neoliberal paradigm's major narrative that is the problematic mythology in shaping much of humanity's relationship to the world and the institutions that we have created. Arguably that narrative needs to shift rather dramatically before the world can begin to get 
better. To create a narrative that is more appropriate for the current state of the world, modern shamans need to 'journey' across disciplines to collect and use information that can inform the new, more complex narrative needed today.

The shaman often implicitly understands the importance of memes in shaping the cultural narrative that affects the community. In contrast to traditional shamanic beliefs, much of Western culture is characterized by a split between mind and body, as well as between 'man' (sic) and nature. Similarly, we see businesses as somehow separate from society rather than as an integral part of societies, which themselves are integrally related to the natural environment, not separate from it. The reality is, however, that as human beings we are creatures of Nature, integrally tied to it, and literally cannot survive without her resources and an environment supportive of human civilizations. We figuratively and literally need the other living beings in the world that support the ecosystems in which we live and the resources on which they... and we...depend (e.g., Capra and Luisi 2014). It is this reality that makes the current dominant narrative so problematic for humans.

\section{Myth Busting and Meme Shaping}

Think for a moment about what today's global dominant cultural narrative about the roles of businesses in society is - and the memes that dominate the news cycle. A sample of dominant businesses and economic memes suggests that for businesses and economies (notably, not societies) to be effective, there should be:

- Free markets and private property: deregulate, privatize, free up markets from all constraints to enhance movement of capital, goods, and services through market-based pricing mechanisms.

- Free, rational, and responsible individuals (translated into libertarianism): Individuals make their own choices. People are responsible for their situations and need to fend for themselves. There is no 'public good' or community welfare, and there should be no public welfare support.

- Free trade: economic integration, globalization, liberalization, harmonization of laws globally will enhance trade and therefore overall welfare because every nation has a comparative advantage that it can tap.

- Laissez-faire economics: smallest possible government, reduced social welfare expenditures.

Never mind that these memes and their associated policies and practices have created an ecologically (and as the 2007-8 Global Financial Crisis suggest, perhaps financially) unsustainable system, ever-greater human-induced climate change, growing inequality, and global jobs crisis. True believers in this 'neoliberal' agenda overlook these consequences because for some people, i.e., those people the Occupy movement characterized as the $1 \%$, these memes (i.e., a memeplex or collection of memes in a narrative) (Blackmore 2000) work very well. But they are not working so well for the rest of us.

Dominant memes are mainly derived from the neoliberal agenda articulated by the Mont Pelerin Society ${ }^{3}$ and its evolution into what is known as neoclassical economics, promulgated prominently by the so-called Chicago School of Economics, whose most prominent

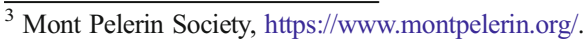


spokesman was Milton Friedman. ${ }^{4}$ Busting the myths associated with these memes is important to building a future where all can thrive. The current mythology has resulted not just in the Global Financial Crisis of 2007-8, the growing gap between rich and poor, but also the overuse of natural resources, excessive consumption and materialism, out of control global population growth, climate change, unsustainable agricultural and food production practices, and the sustainability crises that now affect the entire planet, and some even might say the terrorism that now pervades the world.

To shift business and economic practice, arguably we need to shift the current memes and associated narrative to ones that support a combination of wellbeing, vitality, dignity, inclusivity, diversity, and humans living in harmony with nature. ${ }^{5}$ We need, in short, an alternative narrative that resonates broadly, stands on its own, and offers hope for all, provides a positive vision of the future, and addresses major concerns in what can sometimes look like a hopeless context. That is, we need to substitute new memes that support a new cultural 'myths' or stories aligned with nature's resources and equitable flourishing societies. Fundamentally, we need a new 'origin story' that helps us realign and rebalance humans' relationship to the rest of the world, including other living creatures.

\section{The Current Dominant (Neoliberal) Narrative}

What is the end goal of an economy, a society, or even a business? Most economists and politicians today, not to mention the media, would say the goal is constant growth, i.e., growth that maximizes shareholder wealth, market share, and profits for businesses. For societies, aka economies, GNP growth has become the standard bearer, despite known problems with how it is constructed (e.g., Costanza et al. 2009). Growth, in this narrative, involves 'free' markets, individualism, globalization, and laissez-faire governments. The left side of Table 1 lists some core memes out of which the current dominant narrative is constructed (and much of which can be found in any basic economics textbook). The online 'Urban Dictionary' illustrates this narrative, defining neoliberalism as follows:

Neoliberalism is an economic ideology centered around the values of a global economy, or globalization: free market, free trade, and the unrestricted flow of capital. Neoliberals advocate minimal government spending, minimal taxation, minimal regulations and minimal direct involvement in the economy, ... and believe market forces naturally fill many areas of jurisdiction for the highest overall gain. ${ }^{6}$

In another definition, the World Health Organization defines neoliberal ideas as 'the philosophy that underpins and drives economic globalization. At its core is a belief in the free market and minimum barriers to the flow of goods, services and capital. It is an extension of the traditional liberal philosophy, which argues for a separation of politics and economics and that markets should be "free" from interference of government. This approach is based on four principles:

\footnotetext{
${ }^{4}$ E.g., Richard M. Ebeling, Milton Friedman and the Chicago School of Economics, http://fee. org/articles/milton-friedman-and-the-chicago-school-of-economics/. December 1, 2006. See also, Economics Help, http://www.economicshelp.org/blog/glossary/chicago-school/; https://en.wikipedia.org/wiki/Chicago_ school_of economics;

${ }^{5}$ Here I would note that this agenda follows thinking that has been advanced by the Humanistic Management Network and a working group called Leading for Wellbeing, of which the author is a part.

${ }^{6}$ Urban Dictionary, http://www.urbandictionary.com/define.php?term=neoliberal.
} 
Table 1 Core memes in the current/proposed narrative on wellbeing, dignity, and vitality

\begin{tabular}{|c|c|c|}
\hline Focus & Neoliberal/Economic Narrative & Wellbeing/Dignity Narrative \\
\hline Systemic orientation & Free enterprise system (economy) & $\begin{array}{l}\text { Societies (with embedded markets) } \\
\text { in Nature (holistic) }\end{array}$ \\
\hline Dominant goals & $\begin{array}{l}\text { Growth } \\
\text { - Economic (GNP/GDP) } \\
\text { - Wealth: Financial wealth } \\
\text { - Business growth (shareholder } \\
\text { wealth/profits) } \\
\text { - Consumption and materialism }\end{array}$ & $\begin{array}{l}\text { Wellbeing and dignity for all, } \\
\text { planetary stewardship } \\
\text { - Wealth: Collective value (Gini, GPI) } \\
\text { - Dignity and reverence for humans, } \\
\text { living beings, Nature's manifestations }\end{array}$ \\
\hline Wealth Capital(s) & Financial wealth & $\begin{array}{l}\text { Wealth as vitality, generativity } \\
\text { - Economic/financial } \\
\text { - Human/intellectual } \\
\text { - Social/relational } \\
\text { - Natural/ecological } \\
\text { - Spiritual/reverence }\end{array}$ \\
\hline Core values & $\begin{array}{l}\text { Freedom/liberty (libertarianism) } \\
\text { - Free markets/economic freedom } \\
\text { - Globalization, free trade } \\
\text { - Individualism (free, rational, } \\
\text { responsible, self-interested } \\
\text { individuals) } \\
\text { - Private property/goods, } \\
\text { consumption, materialism } \\
\text { - Competition }\end{array}$ & $\begin{array}{l}\text { Freedom and democracy within } \\
\text { constraints of dignity and an } \\
\text { ecologically sustainable } \\
\text { social contract } \\
\text { - Fair markets aligned with societal/ } \\
\text { ecological values } \\
\text { - 'Glocal'-ism, fair trade, federalism } \\
\text { with subsidiarity } \\
\text { - Respect for individuals in community } \\
\text { contexts, Ubuntu } \\
\text { - Private and public goods, harmony, } \\
\text { 'enough stuff,' restoration, } \\
\text { regeneration, generativity } \\
\text { - Collaboration and competition }\end{array}$ \\
\hline Governmental roles & $\begin{array}{l}\text { Laissez-faire } \\
\text { - Reduce/eliminate government } \\
\text { and social welfare benefits }\end{array}$ & $\begin{array}{l}\text { Rule of (fair) law/regulation } \\
\text { - Avoid market failures, externalities } \\
\text { - Baseline social welfare for all } \\
\text { - Balance civil society, governmental, } \\
\text { business imperatives }\end{array}$ \\
\hline $\begin{array}{l}\text { Business purpose and bottom } \\
\text { line(s) }\end{array}$ & $\begin{array}{l}\text { Maximize shareholder } \\
\text { wealth and profits } \\
\text { - Scale, efficiency, } \\
\text { productivity }\end{array}$ & $\begin{array}{l}\text { Maximize aggregate wellbeing } \\
\text { (prosperity) within ecological } \\
\text { constraints without dignity violations } \\
\text { - Job stability and creation, decent work, } \\
\text { restorative businesses, ecologically } \\
\text { beneficial } \\
\text { - Balance, harmony }\end{array}$ \\
\hline
\end{tabular}

- Economic growth is paramount: corporations and their agents need to be free to pursue whatever gives them an economic advantage and, in consequence, internal and global markets must be free to operate with little government constraint or regulation;

- Free trade benefits all nations - rich or poor-because every nation has a comparative advantage;

- Government spending creates inefficiency and waste; ...

- In the distribution of economic goods, individual responsibility replaces the concepts of public goods and community.,

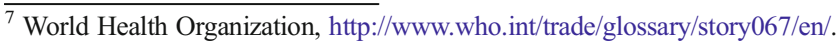


Thus, using the memes identified in the left column of Table 1, the currently dominant neoliberal narrative can be stated as:

Businesses and economies operate best with free markets, free economies, and free trade on a global scale, that is, with as few rules and restrictions as possible. Growth is a core objective of this system because free and unregulated markets are expected to benefit everyone. Further, free markets take care of most if not all problems. The bottom line is financial wealth, measured in maximized shareholder wealth and profitability for businesses and growth in gross domestic/national product for countries/societies (or, as they are known, 'economies'). Private property is a core value, thus privatization of what might have once been considered public goods is advocated, along with 'laissez-faire' government, i.e., deregulation or as little government regulation/intervention in markets as possible, since such regulation might reduce profits. Competition, among businesses and even nations, is a hallmark of the free enterprise system as thus defined, with a winner-take-all attitude based on individualism and libertarianism, free trade, economic freedom, and social Darwinism, favoring policies that include economic liberalization, privatization, fiscal austerity, deregulation, free trade, and spending limitations for governmental agencies.

In today's global context, neoliberal philosophy has resulted in harsh and growing inequality, climate change, and ecological unsustainability, to name a few issues, and is increasingly obviously no longer the best path forward.

\section{Advancing New Memes and a New Narrative}

One of the first things to notice about any modern narrative is that takes place in a dynamic, rapidly evolving, and hugely problematic context quite different from the 'threat to free enterprise' originally identified by the Mont Pelerin Society. This context is notably more complex than an economic narrative alone can cover. Further, whatever choices we - humanity - make for the near term are likely to affect the long term wellbeing of humans on the planet. Finding a narrative that brings humanity, businesses, economies, and political, and civil society systems into harmony and balance with nature's resources and constraints is central to establishing a flourishing future for humankind. New memes are essential to shifting the mindset of major players in today's systems, for as Meadows (1999) argued, mindset shift is the most powerful system change lever.

Table 1 identifies core memes in the current neoliberal narrative and provides some suggestions of alternatives that might be used to construct a new narrative. Though the new set of memes are not as simple (simplistic?) as neoliberal memes, the added complexity of addressing the whole system rather than just the economic system is essential for the more complex message associated with developing a narrative that takes today's realities into account.

Overall, the new narrative ${ }^{8}$ needs to value wellbeing, vitality, dignity, and planetary stewardship, creating core memes around these ideas, not just economic and financial interests. It also needs to take into account the moral, democratic, and ecological conundrums now facing humanity as a consequence of current policies (Speth 2012), and establish values of what I will call reverence - for other people, even people different from oneself, for nature and

\footnotetext{
${ }^{8}$ Full disclosure: I am part of a group called Leading for Wellbeing, which is led by Michael Pirson of Fordham University and L. Hunter Lovins of The Natural Capitalism Institute, which is explicitly working on the new narrative.
} 
all her manifestations, and for whatever brings 'awe' into life, including reverence for a higher power or simply the majesty of the universe. The new narrative needs to foster dignity, equity, fairness, and a collective sense of harmony, collaboration mixed with competition, and balance. Such a narrative suggests quite a different 'take' on the roles of businesses in society and indeed of societies' relationship with the natural environment than the currently dominant narrative fosters.

Below, the paper explore the memes out of which such a new narrative might be constructed (Table 1).

Systemic Orientation The main systemic focus of the neoliberal agenda, as articulated by the Mont Pelerin Society in $1947,{ }^{9}$ was to 'save' the free enterprise system, which was viewed as being under threat. This focus is by its nature economic, hence all of the prescriptions associated with the neoliberal agenda, especially as they became operationalized in what is known as neoclassical economics are focus on economic growth, economic capital, with economic and financial values taking center place, and diminished governmental roles.

Today's civilizational threat is different: it is fundamentally a threat to humanity and other living beings, as the planet is experiencing a sixth and only human-induced 'great extinction' (Barnosky et al. 2011; Larsen 2004; Leakey and Lewin 1996), sustainability, climate change, inequality, and jobs crises. While the current economically-based narrative fosters the belief that economies and societies are the same things, today's threat is existential in the sense that if the system does not change in a holistic way, the twin threats of inequality and climate change could potentially result in systemic collapse or, at minimum, severe disruption (e.g., Diamond 2005; Gilding 2011; Jackson 2011; Ehrenfeld and Hoffman 2013; Fullerton 2015).

Given the nature of today's threats, a new narrative's core memes need to focus not simply on economies, but on the broader societies of which economics are a part, and of mankind's relationship to Nature as a whole. Today's difficult times call for a form of planetary stewardship that has not yet been broadly experienced.

Well-being, Dignity, Planetary Stewardship The idea of growth has been centrally important to economics and business thinking since WWII, although as Piketty (2014) demonstrates, growth was not always considered an imperative of economic and business systems. 'Growth' emphasizes economic growth as measured by GNP/GDP, financial wealth, business growth (e.g., in shareholder wealth and profits, also market share, and organizational size). The growth narrative emphasizes materialism and consumption of goods privately as a by-product.

Thinking about what memes make sense for a new narrative in a sustainability and resource-constrained context, it is important to note the fundamental problems with growth as a core societal, economic, and business meme. Thomson (2011); also Meadows et al. (1972), for one, argues that 'the idea that infinite growth on a finite planet is not possible is now creeping into our consciousness' (Thomson 2011, p. 448). Indeed, the core question for the future may well not be whether to grow or not (or how much to grow), but how to cope with a lack of real growth - and what to substitute for growth as an economic or business objective. Lack of economic growth is already evident in many global economic statistics since the Global Financial Crisis of 2007-2008 (c.f., Kallis et al. 2012), though global population growth (problematically) continues. The growth mindset is pervasive throughout

${ }^{9}$ Mont Pelerin Society, https://www.montpelerin.org/. 
societies. Just look at the evening news to be reminded of the importance of stock market growth and economic growth, both deeply embedded in our collective psyche. In the context described above, however, continual financial wealth growth implies continual material growth, which means more resource consumption on a planet where many ecosystems are already hitting limits. As Ehrenfeld and Hoffman (2013), Heinberg (2011), Randers (2012), Jackson (2011), and others have argued, such growth trajectories are simply not feasible on a finite planet.

The concepts of wellbeing and dignity for all (alternatively, flourishing, thriving, 'better not bigger') as substitutes for the growth meme provide core memes that can foster both inclusiveness and diversity. This frame also reflects a sense of fairness, justice, and being better off for all, where all can be inclusive of other living beings and nature itself, creating a form of planetary stewardship. The idea of stewardship has a great deal of resonance for many people, because it is closely aligned with many spiritual traditions, yet also provides a frame that can be attractive to non-believers, indigenous peoples with very different from the mainstream spiritual traditions, and people of many different traditions.

Wellbeing is similarly resonant, carrying meanings that encompass prosperity, health, happiness, and success. The idea of wellbeing further applies across a variety of states including psychological, social, economic, spiritual, and health. Wellbeing can apply to a number of life domains as well. The OECD, for example, has a 'Better Life Index' that is constructed of eleven different dimensions of wellbeing that it considers essential that relate to 'material living conditions and quality of life.' These eleven indicators include housing, income, jobs, community, education, environment, civic engagement, health, life satisfaction, safety, and work-life balance. ${ }^{10}$

Obviously 'wellbeing' is more complex to measure than is financial or economic growth, which can be assessed with a currency-based metric. Wellbeing is inherently multidimensional, but that complexity is also a benefit in that it implicitly requires a more systemic perspective than 'growth,' which his typically measured in profitability and shareholder wealth terms for businesses, and GNP/GDP terms for whole economies (i.e., societies). Moving away from an overreliance on GNP and GDP to assess the state of the economy is important, as these measures have been known to be flawed since their inception. GNP/GDP includes economic activity that is paid for and also include negative as well as positive developments (e.g., Van den Bergh 2011; Costanza et al. 2009; Fleurbaey 2009; Landefeld et al. 2008; Stockhammer et al. 1997, c.f., Kuznets 1973).

When we think about wealth in the current narrative, we think primarily about financial wealth. Yet the concept of wellbeing implies a much broader notion of wealth, which encompasses what Donaldson \& Walsh (2015) writing about a theory of business call collective value. They define 'collective value' as 'the agglomeration' of benefits to business participants (i.e., stakeholders) 'net of any aversive business outcomes' (Donaldson \& Walsh, p. 188). A more sweeping perspective on collective value is addressed in emerging, sustainability and wellbeing-oriented measures like the Genuine Progress Indicator (GPI), which measures 'what really matters to people - health care, safety, a clean environment and other indicators of wellbeing' in a way that shifts policy towards sustainability. ${ }^{, 1}$

Donaldson \& Walsh (2015) also point to the importance of business activities not producing dignity violations (Hicks 2011) in the course of doing business. Although Donaldson \& Walsh

\footnotetext{
${ }^{10}$ OECD, Better Life Index, http://www.oecdbetterlifeindex.org/.

${ }^{11}$ Redefining Progress, http://rprogress.org/index.htm, Genuine Progress Indicator, http://rprogress. org/sustainability_indicators/genuine_progress_indicator.htm.
} 
(2015) suggest that it is possible that other creatures beyond human beings might also be accorded dignity, they stop short of what I believe is necessary: not only should humans be treated with dignity, but also all other living beings and, importantly, 'Mother Nature' herself in all of her manifestations. From the shamanic perspective noted earlier, all beings and Earth itself have spirit - and hence need to be treated with dignity. If we think about businesses, for example, as being 'restorative,' working in what is being called the circular economy, or using methods of natural capitalism (Hawken et al. 2013), then in the future businesses will look and act very differently than they do today. As Donaldson \& Walsh suggest, they will need to act with collective value and dignity (of all manifestations of nature, human and other, including 'nonliving' elements) in mind. They will need purposes that align them with the wellbeing of the societies in which they operate and with the ability of the natural world to support human civilization - and other aspects of nature.

Vitality and Generativity Today's dominant narrative focuses businesses - and the rest of us - on accumulating ever more financial wealth to measure personal and businesses success. Yet a good deal of research suggests that beyond a certain point at which life's basic important needs are met, accumulating ever-more financial wealth does not necessarily lead to greater happiness or better wellbeing (Csikszentmihalyi 1999). Oxfam (2016) finds that 62 people now control as much financial wealth as the least wealthy half of the world's population. It is increasingly clear that the current system is geared to producing ever-greater monetary or financial wealth for the already wealthy (c.f., Piketty 2014) to the detriment of the wellbeing of most of the rest of the world's population. Among the things that people actually seem to need to experience wellbeing, according to happiness research, are enough wealth to support self and family, community, strong relationships, satisfying work or other activities, and what Csikszentmihalyi (1999) calls the experience of flow or being at one with what one is doing.

Imagine enhancing financial and ecological wealth with another set of 'capitals' (Table 1) associated with vitality and generativity (Fullerton 2015). Vitality and generativity can be enhanced through sufficient financial/economic wealth to support people and their families. Other forms of capital become important in thinking about promoting vitality. Human and intellectual capital can provide people meaningful and decent work where they can truly contribute to something bigger than themselves, have outlets for creative pursuits of all sorts, and an educational basis that provides the kinds of opportunities that generate meaningful lives, connections and relationships, and whole communities. The need for meaningful connections and relationships suggests that social and relational capital are also important, because for many people a major source of vitality and generativity occurs in the context of relationships and communities acting together on common purposes.

Further, given the sustainability challenges of the world, generating more harmonious and regenerative relations between humans and nature is central to creating greater vitality overall. Closing the human/Nature gap that has beset Western cultures since Descartes declared 'I think therefore I am,' separating mind from body, is vital to resolving the mind-body and ultimately the human-nature split. Allowing ecosystems to flourish and humans to understand our intimate relationships and connections with natural systems is a crucial element of creating vitality and generativity, since humans cannot flourish without a flourishing natural environment that is capable of supporting human civilizations and, ultimately, everything is connected (Capra and Luisi 2014; Capra 1995; (e.g., Jackson 2011; Hawken et al. 2013; Ehrenfeld and Hoffman 2013). 
Relatedly, human connections in communities, families, and societies are essential elements of vitality and generativity at a whole variety of levels, including family, organizations, communities, and whole societies. Social (Putnam 2001) and relational capital are vital to creating flourishing human communities. Both diversity and connections among people (and natural beings/manifestations) create resilience and capacity for success in a system (e.g., Porter 1998), while monolithic structures and systems (think monocultures in agriculture) create the potential for systemic problems, even collapse, because they lack sufficient resiliency (i.e., are 'too big to fail' in the lexicon of the 2007-08 Global Financial Crisis).

Another meme that provides a framework for action in the context of wellbeing, dignity, and planetary stewardship is a meme of 'reverence.' Replacing what amounts to reverence today for consumption, material goods, and the 'latest best thing' (materialism) with reverence for other people, other living beings, and Nature and all of her manifestations would bring a very different mindset to the human activities in the world, including those of businesses. Such reverence includes reverence and respect for whatever higher power that different peoples believe in. Reverence forms the possibility for what can be called restorative business in a context of what Fullerton (2015) calls a regenerative economy.

Core Values The core values dominant in the neoliberal narrative find their foundations in values of freedom and liberty. Over time these values have been operationalized as libertarianism and ardent individualism, which argues that individuals are and need to be free, are rational and selfinterested, and responsible for their actions. Freedom and liberty get expressed in purportedly 'free' markets and through ideals economic freedom, free trade in a globalized world. Competition is highly valued in the existing narrative, as are private property and private goods. Businesses, which are expected to constantly grow in market share, size, and profits, seek scale, efficiency, and productivity enhancements to meet the private needs of individuals for private 'goods,' with little respect or regard for public goods, community, or the types of infrastructure and interventions that governments make (see next section) to develop or maintain such public goods.

A wellbeing, dignity, and planetary stewardship narrative complements existing core values around liberty and freedom with the recognition that we must all live together on one planet that has limited resources. Freedom and its relative, democracy, including the ability to participate actively in governance activities at multiple levels, remain important. Nonetheless, we must be clear that the no-holds barred approach to individual, business and economic activities, population growth, and development at all costs implied (and practiced) under the dominant narrative is no longer feasible. Thus, a new narrative's core values revolve around an ecologically sustainable and dignity-based social contract that both provides opportunities for and constrains human activities, especially business activities.

Consider, then, what values make sense in a new narrative, particularly about businesses in society. Rather than 'free' markets (that are, in fact, anything but free by Adam Smith's definition), we need to establish 'fair markets.' Fair markets would be aligned with societal and ecological values and constraints, regulated so that opportunity is available to all, and supported by tax policies that generate greater equity (see Piketty 2014; Reich 2015).

Counterpoint to globalization, which presumably is here to stay in our connected world, is the idea of 'glocalism,' which recognizes that some things (telecommunications technologies, as an example) are almost necessarily global, while other things can and probably should be local. Although the term is typically used to mean global companies adapting to local markets, as used here 'glocal' carries the implication of fair trade for local producers operating into global markets, 
devolving production and other operations to the most local possible level, i.e., a form of trade federalism with subsidiarity on global and local scales.

The rampant individualism found in the neoliberal narrative would be exchanged for respect for individuals in the context of broader communities and nature at multiple different levels, in recognition of the inherent interdependence of humans with each other and with nature. Such a community-based sense of individuals recognizes their individuality but also the importance of community in shaping, fostering, and enhancing the wellbeing of the individual, in the sense that 'it takes a village' not just to raise a child as the African saying goes, but to create a healthy, prosperous community (and, more broadly, society) where all can thrive. Such a value is often found in African communities, who use the concept of Ubuntu, the notion that 'I am because we are' or 'humanness,' to mean that we are all connected together in our humanity.

The neoliberal narrative values private goods, privatization, and private property to the exclusion of public goods and public property. A new narrative recognizes the important roles that effective governments play in the provision and protection of necessary public goods, i.e., goods widely recognized to be indivisible and essential to community wellbeing. Public goods include clean water and air, public parks, education, and, in most developed nations, healthcare, among others. New narrative values could focus on the need for both private and public goods, as appropriate to the nature of the goods and within ecological and community limits. Values that foster sufficiency or 'enough stuff,' restoration of what still works, durability, quality, regeneration, and generativity, rather than constant product churn, replacement (and consequent throwing away) of goods will be needed.

Strict values of competition over other forms of interacting need to be replaced with the recognition that like many biological systems, humankind is in an epigenetic type of relationship with nature, with industries, and with communities. in which things co-evolve simultaneously and mutually change (in the process called epigenetics, e.g., Lipton and Bhaerman 2009). Biological systems evolve through symbiosis, that is, collaboration, with other biological systems, not simply as a result of competition (e.g., Capra and Luisi 2014). A new narrative values both collaboration and competition for the different impulses that they bring to businesses and other institutions.

Governmental Roles In the neoliberal framework, the attitude toward government is 'laissez-faire,' let it be. In other words, there should be as little government as possible and equally little governmental intervention in the affairs of markets and businesses, or other aspects of human life. With all due recognition that governments can be inefficient at times and in some places quite corrupt, a new narrative acknowledges that, as with public goods above, there are some roles that only the coercive powers of governments can fulfill. Creating laws that actually allow markets to work fairly rather than being a free-for-all is one example. Limited or no government needs to be replaced with the rule of fair laws and regulations that actually support some democratically-defined version of the public good, within realistic constraints imposed by nature and dignity. Governments need to find creative new ways to avoid market failures and handle the externalities that businesses and markets create, with the objective of baseline social welfare (wellbeing) for all, including nature and her manifestations. This governmental perspective suggests a difficult balancing act among the interests of businesses, civil society institutions, and 
governmental imperatives. What the rule of fair law does is recognize that markets do not and cannot solve all problems and that there is vitally important role for government in coping with the vital issues of the day.

Business Purposes and Bottom Lines One final area where the narrative needs to shift is around the purpose of business. Today, business purpose is too often wrongly understood as maximizing shareholder wealth (see, Stout 2008, 2012). Following Donaldson \& Walsh (2015), a new narrative needs to redefine the purpose of future businesses as maximizing aggregate wellbeing - or collective value in their terms - within ecological constraints and without violating dignity.

Aligned in the dominant narrative with maximization of profits are values of scale, efficiency, and productivity. None of these values are inherently problematic, however it is clear that there are many stakeholders who contribute actively to the health, wellbeing, and profitability of a company, well beyond shareholders (Freeman 1984; Waddock and Rasche 2012), many of whom may not even be aware of what they 'own' (Handy 2002). Values of scale, efficiency, and productivity need to be complemented by additional values that expand the purposes of business to deal with overall prosperity for all stakeholders, not just wealth for shareholders. Some decisions will likely need to be made not just because 'that's how business does things,' but with ecological and dignity-based interests firmly in mind-even if such decisions reduce profitability in the short term in the interests of the greater whole. If the goals of businesses expanded to include job development and security, decent and meaningful work, community stability, and ecological and community flourishing, and ecological sustainability, then business operations could be much better aligned with the greater needs of humanity and the world's other living beings and systems. Granted, such indicators would not be as 'efficient' as the financial bottom line is in generating a look at companies' performance; they would, however, be more effective from a societal perspective (Drucker 1967). Numerous initiatives, including the Global Reporting Initiative, Integrated Reporting, and social investment ratings already suggest the feasibility of developing and using these more complex indicators.

\section{Conclusion}

This paper has argued for and set out new memes needed to inform a new narrative about societies and the businesses engaged in them in a future constrained by ecological considerations and growing global inequality, among other major issues. This new narrative needs to be comprised of memes that focus on wellbeing, dignity, inclusiveness, diversity, and planetary stewardship. Indeed, such a new narrative is not only possible at this time but is necessary in light of possible existential threats to human civilization as we know it. Shifting the memes that dominate the conversation about businesses in society from the neoliberal agenda that has so embedded that we hardly realize that it does not represent the only way of viewing businesses and societies will not be easy. Making that transition is, however, a necessary part of shifting the mindsets of people around humankind's relationship to the world around, and, as Meadows (1999) pointed out shifting mindset is perhaps the most important change lever when we are attempting systemic change. 
Acknowledgments The author would like to acknowledge the Humanistic Management Network, particularly Michael Pirson, and the Leading for Wellbeing Consortium's contribution to the thinking in this paper.

\section{References}

Barnosky, A.D., N. Matzke, S. Tomiya, G.O. Wogan, B. Swartz, T.B. Quental, C. Marshall, J.L. McGuire, E.L. Linsey, K.C. Maguire, B. Mersey, and E.A. Ferrer. 2011. Has the Earth/'s sixth mass extinction already arrived? Nature 471(7336): 51-57.

Blackmore, S. 2000. The meme machine. Oxford University Press.

Capra, Fritjof. 1995. The Web of Life. New York: Anchor Doubleday.

Capra, F., and P.L. Luisi. 2014. The systems view of life: A unifying vision. Cambridge University Press.

Costanza, R., M. Hart, S. Posner, and J. Talberth. 2009. Beyond GDP: The need for new measures of progress. The Pardee Papers 4: 46.

Csikszentmihalyi, Mihaly. 1999. If we're so rich, why aren’t we happy? American Psychologist 54(10): 821-827.

Diamond, J. 2005. Collapse: how societies choose to fail or succeed: revised edition. New York: Penguin.

Donaldson, T., and J.P. Walsh. 2015. Toward a theory of business. Research in Organizational Behavior 35: 181207.

Dow, J. 1986. Universal aspects of symbolic healing: A theoretical synthesis. American Anthropologist 88(1): 56-69.

Drucker, P.F. 1967. The effective executive, vol. 967. London: Heinemann.

Egri, C.P., and P.J. Frost. 1991. Shamanism and change: bringing back the magic in organizational transformation. Research in Organizational Change and Development 5: 175-221.

Ehrenfeld, J., and A. Hoffman. 2013. Flourishing: A frank conversation about sustainability. Palo Alto: Stanford University Press.

Fleurbaey, Marc. 2009. The quest for a measure of social welfare. Journal of Economic Literature 47(4): 10291075.

Freeman, R.E. 1984. Strategic planning: A stakeholder approach. Boston: Pitman.

Frost, P.J., and C.P. Egri. 1994. The shamanic perspective on organizational change and development. Journal of Organizational Change Management 7(1): 7-23.

Fullerton, John. 2015. Regenerative capitalism: How universal principles and patterns will shape our new economy. Greenwich, CT: Capital Institute. Posted at: http://capitalinstitute.org/wp-content/uploads/2015/04 /2015-Regenerative-Capitalism-4-20-15-final.pdf.

Gilding, P. (2011). The great disruption: How the climate crisis will transform the global economy. Bloomsbury Publishing.

Handy, C. 2002. What is a business for. Harvard Business Review 80(12): 48-55.

Hawken, P., A.B. Lovins and L.H. Lovins. 2013. Natural capitalism: The next industrial revolution. Routledge.

Heinberg, R. (2011). The end of growth. Gabriola Island, BC, Canada: New Society Publishers.

Hicks, D. 2011. Dignity: The essential role it plays in resolving conflict. New Have: Yale University Press.

IPCC. 2014. Summary for policymakers. In Climate change 2014: Impacts, adaptation, and vulnerability. Part A: Global and sectoral aspects. Contribution of Working Group II to the Fifth Assessment Report of the Intergovernmental Panel on Climate Change, ed. C.B. Field, V.R. Barros, D.J. Dokken, K.J. Mach, M.D. Mastrandrea, T.E. Bilir, M. Chatterjee, K.L. Ebi, Y.O. Estrada, R.C. Genova, B. Girma, E.S. Kissel, A.N. Levy, S. MacCracken, P.R. Mastrandrea, and L.L. White, 1-32. Cambridge and New York: Cambridge University Press.

Jackson, T. 2011. Prosperity without growth: Economics for a finite planet. Abington: Routledge.

Kallis, G., C. Kerschner, and J. Martinez-Alier. 2012. The economics of degrowth. Ecological Economics 84: $172-180$.

Kuznets, Simon. 1973. Modern economic growth: findings and reflections. The American Economic Review 63(3): 247-258.

Landefeld, J. Steven, Eugene P. Seskin, and Barbara M. Fraumeni. 2008. Taking the pulse of the economy: Measuring GDP. The Journal of Economic Perspectives 22(2): 193-216.

Larsen, J. 2004. The sixth great extinction: a status report. Humanist-Buffalo 64(6): 6.

Leakey, R., and R. Lewin. 1996. The sixth extinction: Biodiversity and its survival. London: Weidenfeld and Nicolson.

Lipton, Bruce H., and Steve Bhaerman. 2009. Spontaneous evolution: Our positive future and how to get there. New York: Hay House.

Lovelock, James. 2010. The vanishing face of Gaia: A final warning. New York: Basic Books. 
Meadows, Donella. 1999. Leverage points: Places to intervene in a system. Harland, VT: The Sustainability Institute. Posted at: http://donellameadows.org/archives/leverage-points-places-to-intervene-in-a-system/.

Meadows, D.H., D.H. Meadows, J. Randers, and W.W. Behrens III. 1972. The limits to growth: A report to the club of rome (1972). New York: Universe Books.

Oxfam (Deborah Hardoon, Sophia Ayele, and Ricardo Fuentes-Nieva). 2016. An economy for the 1\%: How privilege and power in the economy drive extreme inequality and how this can be stopped. January 18, 2016, 210 Oxfam Briefing Paper, Summary. Posted at: http://policy-practice.oxfam.org.uk/publications/aneconomy-for-the-1-how-privilege-and-power-in-the-economy-drive-extreme-inequ-592643/.

Piketty, Thomas. 2014. Capital in the twenty-first century. Cambridge: Harvard University Press.

Porter, Michael E. 1998. "Clusters and the New Economics of Competition." Harvard Business Review, November-December, 77-90.

Putnam, R.D. 2001. Bowling alone: The collapse and revival of American community. New York: Simon and Schuster.

Randers, J. (2012). 2052: A global forecast for the next forty years. White River Junction, VT: Chelsea Green Publishing.

Raworth, K. 2012. A safe and just space for humanity: can we live within the doughnut. Oxfam Policy and Practice: Climate Change and Resilience 8(1): 1-26.

Reich, Robert B. 2015. Saving capitalism: For the many, not the few. New York: Knopf.

Rockström, J., Steffen, W.L., Noone, K., Persson, Å., Chapin III, F.S., Lambin, E., et al. (2009). Planetary boundaries: exploring the safe operating space for humanity. Ecology \& Society, 14(2): 32. http://www. ecologyandsociety.org/vol14/iss2/art32/.

Speth, J.G. 2008. The bridge at the edge of the world: Capitalism, the environment, and crossing from crisis to sustainability. New Haven: Yale University Press.

Speth, J.G. 2012. American passage: Towards a new economy and a new politics. Ecological Economics 84: $181-186$.

Steffen, W., K. Richardson, J. Rockström, S.E. Cornell, I. Fetzer, E.M. Bennett, R. Biggs, S.R. Carpenter, W. de Vries, C.A. de Wit, C. Folke, D. Gerten, J. Heinke, G.M. Mace, L.M. Persson, V. Ramanathan, B. Teyers, and S. Sorlin. 2015. Planetary boundaries: Guiding human development on a changing planet. Science 347(6223): 1259855-1-1249855-10.

Stockhammer, Engelbert, Harold Hochreiter, Bernhard Obermayr, and Klaus Steiner. 1997. The index of sustainable economic welfare (ISEW) as an alterantive to GDP in measuring economic welfare. The results of the Austrian (revised) ISEW calculation 1955-1992. Ecological Economics 21: 19-34.

Stout, L.A. 2008. Why we should stop teaching Dodge v. Ford. Virginia Law \& Business Review 3: 163.

Stout, L.A. 2012. The shareholder value myth: How putting shareholders first harms investors, corporations, and the public. Berrett-Koehler Publishers.

Thomson, B. 2011. Pachakuti: indigenous perspectives, buen vivir, sumaq kawsay and degrowth. Development 54(4): 448-454.

Van den Bergh, J.C. 2011. Environment versus growth-A criticism of "degrowth" and a plea for "a-growth". Ecological Economics 70(5): 881-890.

Waddock, S. 2015a. Intellectual shamans: Management academics making a difference. Cambridge: Cambridge University Press.

Waddock, Sandra. 2015b. Reflections: Intellectual shamans, sensemaking, and memes in large system change. Journal of Change Management 15(4): 259-273.

Waddock, S., and Rasche, A. (2012). Building the responsible enterprise: Where Vision and values add value. Stanford University Press. 